\title{
OS PONTOS DE PRETO-VELHO NA UMBANDA: RETRATOS DA ESCRAVIDÃO
}

\section{Carollina Roberto Moraes ${ }^{1}$ \\ Paulo Roxo Barja²}

Resumo: A umbanda, uma religião genuinamente brasileira, carrega em sua formação o sincretismo entre as crenças católica, espírita kardecista, indígena e matrizes negras (macumba e candomblé). Com diferentes linhas de trabalho, os pontos cantados durantes as sessões religiosas da linha dos pretos-velhos chamam a atenção por mencionar barbáries sofridas pelos negros na época da escravidão. Para evidenciar a produção e interpretar o sentido dos cantos, o presente trabalho foi desenvolvido principalmente através da pesquisa de campo dentro dos terreiros de umbanda, buscando indicar a ligação entre os pontos cantados e os fatos ocorridos nos tempos de escravidão no Brasil. A pesquisa evidencia que os pontos cantados da umbanda apresentam as marcas da barbárie e podem ser vistos como retratos da escravidão sob o registro da cultura popular.

Palavras-chave: Umbanda; Escravidão; Pontos cantados; Preto velho.

\footnotetext{
${ }^{1}$ Estudante de Jornalismo, Brasil. E-mail: carollinamoraesjor@gmail.com.
}

2 LabCom/FCSAC/UNIVAP, Brasil. E-mail: barja@univap.br. 